\title{
Trend Analyses of Critical Values Obtained for Energy Consumption Fairness Proportion Achievable in Ubicomp MANETs Using Location-Aware Transmission Strategies.
}

\author{
M. Kaleem GALAMALI, Assoc. Prof Nawaz MOHAMUDALLY
}

\begin{abstract}
The fields of location-tracking, ubicomp functionalities and MANET transmission strategies are yielding commendable output and justify the research effort input in them [1-53]. With present research status, the merging of these fields still has a lot to undergo. Correct protocol design approaches is a crucial factor for successful merging of these fields. However, it is currently agreed that such approaches are heuristic in nature and hence unsuitable for implementation [91]. Improvements in middleware services and ubicomp network architecture is also needed $[92,93]$.
\end{abstract}

A well-shaped objective in this direction of ubicomp advancement is achievement of "realism" in design and evaluation of wireless routing protocols [94]. Such investigations may generate components better adapted for studies of predictability in ubicomp. These may be required since "realism" will dripple into every feature related to ubicomp, one of which was studied previously [22] to assess the trend of Energy Consumption Fairness Proportion (ECFP) observable for CBRs under different sets of node densities in a ubicomp environment. This study was reinforced by the related study of trends for each ECFP parameter of equations [38].

To accommodate "realism" in knowledge of these trends, in this paper, the next study required is: "What are observable critical values in ECFP trends over varying node densities and trends of such critical values?" Such knowledge will entail the design of more realistic ubicomp scenarios which are better conducive for more sustained testing of experimental middleware components and communication protocols. This study abides as a followup of prior ones [1-53].

Key terms: Ubicomp- Ubiquitous Computing, MAUCMobile and Ubiquitous Computing, ECFP- Energy Consumption Fairness Proportion, CBR- Constant Bit Rate, MANET- Mobile Adhoc Network, CV- Critical Value.

M. Kaleem GALAMALI,

University of Technology Mauritius (student)

Mauritius

Assoc. Prof Nawaz Mohamudally

University of Technology Mauritius,

Mauritius

\section{Introduction}

Present ubicomp environments may be subject to scant resource equipment. A laudable solution to it is use of
MANETS whereby the load of energy requirements is distributed among cooperating nodes in the topography. This feature is markedly influenced by varying node densities. A previous study [22] was conducted for finding the trends observable for metric ECFP for node densities varying between 7 until 56. The observations were split into two, with respect to a peak value found.

i. Previous to the peak value, trend is linear of form: $F(x)=d * x+f$

ii. From the peak onwards, the trend is exponential: $G(x)=a * \exp (b *(x-c))$

A consecutive study [38] was carried out to mathematically model the five parameters observed above. Results obtained are trusted to serve towards better understanding of the evolution and predictability of ubicomp environments. These progresses, though happening slowly, will enable designers to produce more realistic simulation scenarios over which testing procedures can be applied for new middleware and communication components.

The investigation now required for metric ECFP is the identification of observable $\mathrm{CVs}$ obtained during experiments execution and formulation of corresponding theoretical trend of such CVs over varying node densities. Ten such CVs were observed.

The key contribution of this paper is the development of the trends of variations for each of the ten critical values observed for metric ECFP explained previously [22, 38] over node numbers ranging from 7 until 56. Such information should effectively be presented in the right way to more fluidly assist ubicomp designers to understand the evolution and predictability of ubicomp behaviour and be appropriately prepared to carry credulous simulation scenarios over which new communication protocol features could be tested. The rest of this paper is organised as follows: section 2ECFP Critical Values, section 3- Critical Values Trend Analyses- Metric ECFP, section 4- Conclusion and References.

\section{ECFP Critical Values.}

\subsection{Critical Values Identified.}


Proc. of The Seventh Intl. Conf. On Advances In Computing, Control And Networking - ACCN 2017 Copyright (C) Institute of Research Engineers and Doctors, USA .All rights reserved. ISBN: 978-1-63248-134-4 doi: 10.15224/ 978-1-63248-134-4-01

Ten CVs were identified as follows: Column headings are: $\mathrm{C} 1 \rightarrow$ ECFP CV, C2 $\rightarrow$ Meaning of ECFP CV, C3 $\rightarrow$ Corresponding figure number for the ECFP CV.

\section{C1}

1 Effective total number of communicating 1 nodes.

2 Smallest value of FP.

$3 \%$ communicating nodes at smallest FP value. 3

4 Largest FP value

$5 \%$ communicating nodes at largest $\mathrm{FP}$ value.

6 Smallest FP value of $1^{\text {st }}$ five records

$7 \%$ communicating nodes at smallest FP value 7 of $1^{\text {st }}$ five records

$8 \%$ communicating nodes with $\mathrm{FP}<$ modal 8 value of FP.

$9 \%$ communicating nodes with FP $>$ modal 9 value of FP.

10 Value of FP below or equal to which $98 \%$ of 10 communicating nodes lie.

\section{Table 1: ECFP Critical Values}

\subsection{Experimental Critical Values Obtained.}

The values obtained during experiments have been summarised below. Values have been rounded to a maximum of 9 decimal places. Column heading $\mathrm{NN} \rightarrow$ Node Number.

\begin{tabular}{|c|c|c|c|c|c|}
\hline NN & CV1 & CV2 & CV3 & CV4 \\
\hline 7 & 39726 & 0.0 & 24.316568494 & 6.9 \\
\hline 8 & 39598 & 0.0 & 22.147583211 & 7.9 \\
\hline 9 & 45729 & 0.0 & 19.414375998 & 8.9 \\
\hline 10 & 52462 & 0.0 & 13.951050284 & 9.0 \\
\hline 11 & 58297 & 0.0 & 12.667890286 & 10.5 \\
\hline 12 & 64293 & 0.0 & 11.646680043 & 11.5 \\
\hline 13 & 70845 & 0.0 & 10.443926883 & 11.7 \\
\hline 14 & 76746 & 0.0 & 9.608318349 & 12.6 \\
\hline 15 & 82882 & 0.0 & 8.939214787 & 11.5 \\
\hline 16 & 89052 & 0.0 & 8.336702152 & 12.3 \\
\hline 17 & 95628 & 0.0 & 7.670347597 & 16.4 \\
\hline 18 & 101666 & 0.0 & 7.208899730 & 17.4 \\
\hline 19 & 107775 & 0.0 & 6.853166319 & 18.4 \\
\hline 20 & 113850 & 0.0 & 6.529644269 & 19.3 \\
\hline 21 & 120413 & 0.0 & 6.059976913 & 18.4 \\
\hline 22 & 126393 & 0.0 & 5.722627044 & 19.2 \\
\hline 23 & 132559 & 0.0 & 5.430789309 & 20.1 \\
\hline 24 & 138628 & 0.0 & 5.222610151 & 21.0 \\
\hline 25 & 144722 & 0.0 & 5.023424220 & 21.9 \\
\hline 26 & 151847 & 0.0 & 4.717906840 & 23.5 \\
\hline 27 & 157821 & 0.0 & 4.535518087 & 24.4 \\
\hline 28 & 164089 & 0.0 & 4.414067975 & 25.3 \\
\hline 29 & 170191 & 0.0 & 4.252868836 & 26.2 \\
\hline 30 & 176428 & 0.0 & 4.121227923 & 27.1 \\
\hline 31 & 182026 & 0.0 & 4.035687210 & 24.3 \\
\hline 32 & 188211 & 0.0 & 3.909973381 & 25.1 \\
\hline 33 & 194318 & 0.0 & 3.822085448 & 25.9 \\
\hline 34 & 200385 & 0.0 & 3.701873893 & 26.7 \\
\hline 35 & 206622 & 0.0 & 3.553348627 & 27.5 \\
\hline 36 & 212735 & 0.0 & 3.463463934 & 28.3 \\
\hline 37 & 219868 & 0.0 & 3.327905834 & 29.6 \\
\hline 38 & 226002 & 0.0 & 3.260590614 & 30.4 \\
\hline 39 & 232193 & 0.0 & 3.202508258 & 31.2 \\
\hline 40 & 238523 & 0.0 & 3.148962574 & 32.0 \\
\hline 41 & 244729 & 0.0 & 3.066657405 & 32.8 \\
\hline & & & & \\
\hline
\end{tabular}

\begin{tabular}{|c|c|c|c|c|c|}
\hline 42 & 250725 & 0.0 & 2.973377206 & 32.0 \\
\hline 43 & 257048 & 0.0 & 2.835657154 & 32.8 \\
\hline 44 & 263097 & 0.0 & 2.798967681 & 33.5 \\
\hline 45 & 269502 & 0.0 & 2.727994597 & 34.3 \\
\hline 46 & 275426 & 0.0 & 2.699091589 & 35.1 \\
\hline 47 & 281453 & 0.0 & 2.611448448 & 35.8 \\
\hline 48 & 287436 & 0.0 & 2.558134680 & 36.6 \\
\hline 49 & 293877 & 0.0 & 2.484712992 & 37.3 \\
\hline 50 & 299163 & 0.0 & 2.424765095 & 40.1 \\
\hline 51 & 305322 & 0.0 & 2.344082641 & 40.9 \\
\hline 52 & 311348 & 0.0 & 2.282333595 & 41.7 \\
\hline 53 & 318046 & 0.0 & 2.255648554 & 42.5 \\
\hline 54 & 324300 & 0.0 & 2.221399938 & 43.3 \\
\hline 55 & 330262 & 0.0 & 2.216119323 & 44.1 \\
\hline 56 & 336488 & 0.0 & 2.189974085 & 44.9 \\
\hline
\end{tabular}

Table 2(a): Experimental Critical Values Obtained(1)

NN CV5

$7 \longdiv { 0 . 0 2 5 1 7 2 4 3 1 }$ CV6 CV7 CV8 \begin{tabular}{|l|l|l|l|l|l|l|}
8 & 0.025253801 & 0.3 & 1.431890500 & 46.118490833 \\
\hline
\end{tabular} $9 \quad 0.021867961 \quad 0.2 \quad 1.504515734 \quad 50.838636314$ \begin{tabular}{|l|l|l|l|l|l|}
10 & 0.009530708 & 0.2 & 2.296900614 & 40.383515688 \\
\hline
\end{tabular} \begin{tabular}{|l|l|l|l|l|l|l|}
\hline 11 & 0.008576771 & 0.2 & 2.139046606 & 39.964320634 \\
\hline
\end{tabular} \begin{tabular}{l|l|l|l|l|l|l|}
12 & 0.007776896 & 0.2 & 2.359510367 & 33.468651331 \\
\hline
\end{tabular}

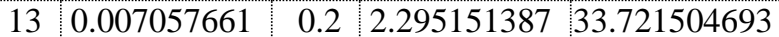
\begin{tabular}{|l|l|l|l|l|l|}
14 & 0.006514998 & 0.2 & 2.198160165 & 33.248638366 \\
\hline
\end{tabular} \begin{tabular}{l|l|l|l|l|l|l}
15 & 0.006032673 & 0.2 & 2.236915132 & 40.802586810
\end{tabular} \begin{tabular}{l|l|l|l|l|l|l|}
16 & 0.005614697 & 0.2 & 2.259354085 & 33.058213179 \\
\hline
\end{tabular} \begin{tabular}{l|l|l|l|l|l|l|}
\hline 17 & 0.005228594 & 0.1 & 2.255615510 & 33.589534446 \\
\hline
\end{tabular}

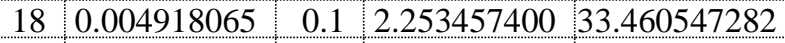
\begin{tabular}{l|l|l|l|l|l|l|}
\hline 19 & 0.004639295 & 0.1 & 2.206448620 & 33.415912781 \\
\hline
\end{tabular} \begin{tabular}{l|l|l|l|l|l|l|}
\hline 20 & 0.004391744 & 0.2 & 2.081686430 & 33.393061045 \\
\hline
\end{tabular} \begin{tabular}{|l|l|l|l|l|l|l|}
21 & 0.004152376 & 0.2 & 2.070374461 & 33.157549434 \\
\hline
\end{tabular} \begin{tabular}{|l|l|l|l|l|l|}
\hline 22 & 0.003955915 & 0.1 & 2.145688448 & 33.289818265 \\
\hline
\end{tabular} \begin{tabular}{l|l|l|l|l|l|l}
23 & 0.003771905 & 0.1 & 2.139424709 & 33.674062116
\end{tabular} \begin{tabular}{l|l|l|l|l|l|l}
24 & 0.003606775 & 0.1 & 2.083273220 & 33.781054332
\end{tabular} \begin{tabular}{l|l|l|l|l|l|l|}
\hline 25 & 0.003454900 & 0.1 & 2.018352427 & 33.647268556 \\
\hline
\end{tabular} \begin{tabular}{l|l|l|l|l|l|}
26 & 0.003292788 & 0.1 & 2.218680646 & 33.461313032 \\
\hline
\end{tabular} \begin{tabular}{|l|l|l|l|l|l|l|}
\hline 27 & 0.003168146 & 0.2 & 2.155606668 & 33.670424088 \\
\hline
\end{tabular} \begin{tabular}{l|l|l|l|l|l|}
28 & 0.003047127 & 0.1 & 2.079968797 & 34.076019721 \\
\hline
\end{tabular} \begin{tabular}{l|l|l|l|l|l|l|l}
29 & 0.002937876 & 0.1 & 2.048874500 & 24.081766956
\end{tabular} \begin{tabular}{l|l|l|l|l|l|l|}
\hline 30 & 0.002834017 & 0.1 & 1.944135851 & 34.222459020
\end{tabular} \begin{tabular}{l|l|l|l|l|l|l|}
31 & 0.002746860 & 0.1 & 1.857426961 & 33.651236637 \\
\hline
\end{tabular} \begin{tabular}{l|l|l|l|l|l|l|l|l}
32 & 0.002656593 & 0.1 & 1.887243572 & 34.050082089 \\
\hline
\end{tabular} \begin{tabular}{l|l|l|l|l|l|l|}
\hline 33 & 0.002573102 & 0.1 & 1.831533877 & 33.969061024 \\
\hline
\end{tabular} \begin{tabular}{l|l|l|l|l|l|l|}
\hline 34 & 0.002495197 & 0.1 & 1.839958081 & 33.961623874 \\
\hline
\end{tabular} \begin{tabular}{l|l|l|l|l|l|l|l|l|l|l|l|l|}
35 & 0.002419878 & 0.1 & 1.788289727 & 33.856510923 \\
\hline
\end{tabular} \begin{tabular}{|l|l|l|l|l|l|}
\hline 36 & 0.002350342 & 0.1 & 1.806002773 & 34.024960632 \\
\hline
\end{tabular}

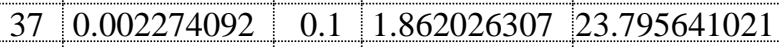
\begin{tabular}{l|l|l|l|l|l|l|}
\hline 38 & 0.002212370 & 0.1 & 1.808833550 & 23.825010398 \\
\hline
\end{tabular} \begin{tabular}{l|l|l|l|l|l|l|}
\hline 39 & 0.002153381 & 0.1 & 1.826067108 & 23.969284173 \\
\hline
\end{tabular} \begin{tabular}{l|l|l|l|l|l|l|l}
40 & 0.002096234 & 0.1 & 1.864809683 & 23.959115054 \\
\hline
\end{tabular} \begin{tabular}{|l|l|l|l|l|l|l|}
\hline 41 & 0.002043076 & 0.1 & 1.788508922 & 34.631367758 \\
\hline
\end{tabular} \begin{tabular}{l|l|l|l|l|l|}
442 & 0.001994217 & 0.1 & 1.779240203 & 23.514607638 \\
\hline
\end{tabular} $43 \quad 0.001945162 \quad 0.1 \quad 1.706296100 \quad 23.541906570$ \begin{tabular}{|l|l|l|l|l|l|l|}
\hline 44 & 0.001900440 & 0.1 & 1.695192267 & 34.551515221 \\
\hline
\end{tabular} \begin{tabular}{|l|l|l|l|l|l|l|}
\hline 45 & 0.001855274 & 0.1 & 1.719838814 & 23.340086530 \\
\hline
\end{tabular} \begin{tabular}{|l|l|l|l|l|l|}
446 & 0.001815370 & 0.1 & 1.666146261 & 23.035588507 \\
\hline
\end{tabular} \begin{tabular}{|l|l|l|l|l|l|}
\hline 47 & 0.001776496 & 0.1 & 1.582857529 & 22.986431127 \\
\hline
\end{tabular}

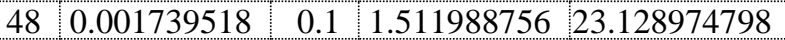

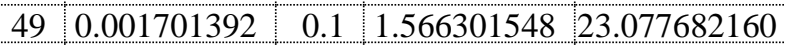
\begin{tabular}{|l|l|l|l|l|l|l|}
\hline 50 & 0.001671330 & 0.1 & 1.548654078 & 23.595832372 \\
\hline
\end{tabular} \begin{tabular}{|l|l|l|l|l|l|}
51 & 0.001637615 & 0.1 & 1.518069448 & 23.370408945 \\
\hline
\end{tabular} \begin{tabular}{|l|l|l|l|l|l|}
\hline 52 & 0.001605920 & 0.1 & 1.510849596 & 23.433906754 \\
\hline
\end{tabular} \begin{tabular}{l|l|l|l|l|l|l|}
53 & 0.001572100 & 0.1 & 1.520534765 & 23.465473548 \\
\hline
\end{tabular}

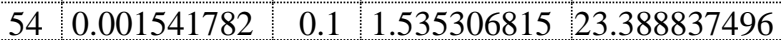
\begin{tabular}{l|l|l|l|l|l|l}
55 & 0.001513950 & 0.1 & 1.494873767 & 23.568863508 \\
\hline
\end{tabular} 
Proc. of The Seventh Intl. Conf. On Advances In Computing, Control And Networking - ACCN 2017

Copyright (C) Institute of Research Engineers and Doctors, USA .All rights reserved. ISBN: 978-1-63248-134-4 doi: 10.15224/ 978-1-63248-134-4-01

$56\left[\begin{array}{l|l|l|l|l}50.001485937 & 0.1 & 1.509117710 & 23.524167281\end{array}\right.$

Table 2(b): Experimental Critical Values Obtained(2)

\begin{tabular}{|c|c|c|}
\hline NN & CV9 & \\
\hline 7 & 45.927100639 & CV10 \\
\hline 8 & 48.487297338 & 3.5 \\
\hline 9 & 43.510682499 & 3.5 \\
\hline 10 & 53.410087301 & 3.6 \\
\hline 11 & 53.246307700 & 3.6 \\
\hline 12 & 59.850994665 & 3.5 \\
\hline 13 & 59.345049051 & 3.6 \\
\hline 14 & 59.261720481 & 3.6 \\
\hline 15 & 51.692768032 & 3.6 \\
\hline 16 & 59.103669766 & 3.6 \\
\hline 17 & 58.014389091 & 3.5 \\
\hline 18 & 58.121692601 & 3.6 \\
\hline 19 & 57.708188355 & 3.6 \\
\hline 20 & 57.423803250 & 3.6 \\
\hline 21 & 57.734629982 & 3.6 \\
\hline 22 & 57.337827253 & 3.6 \\
\hline 23 & 56.942191779 & 3.6 \\
\hline 24 & 56.635023228 & 3.7 \\
\hline 25 & 56.645845138 & 3.6 \\
\hline 26 & 56.732105343 & 3.6 \\
\hline 27 & 56.114205334 & 3.6 \\
\hline 28 & 55.974501642 & 3.6 \\
\hline 29 & 65.890675770 & 3.6 \\
\hline 30 & 55.685605459 & 3.6 \\
\hline 31 & 55.845318801 & 3.6 \\
\hline 32 & 55.479754106 & 3.7 \\
\hline 33 & 55.522905752 & 3.6 \\
\hline 34 & 55.546572847 & 3.6 \\
\hline 35 & 55.498930414 & 3.7 \\
\hline 36 & 55.296025572 & 3.7 \\
\hline 37 & 65.630742082 & 3.6 \\
\hline 38 & 65.569773719 & 3.6 \\
\hline 39 & 65.273285586 & 3.7 \\
\hline 40 & 65.223898744 & 3.6 \\
\hline 41 & 54.476175688 & 3.6 \\
\hline 42 & 65.504835976 & 3.6 \\
\hline 43 & 65.403737823 & 3.6 \\
\hline 44 & 54.432775744 & 3.6 \\
\hline 45 & 65.408048920 & 3.6 \\
\hline 46 & 65.535570353 & 3.6 \\
\hline 47 & 65.500101260 & 3.6 \\
\hline 48 & 65.383250532 & 3.6 \\
\hline 49 & 65.320865532 & 3.6 \\
\hline 50 & 64.899068401 & 3.8 \\
\hline 51 & 64.976320082 & 3.7 \\
\hline 52 & 64.923815152 & 3.7 \\
\hline 53 & 64.826157223 & 3.7 \\
\hline 54 & 64.654640765 & 3.7 \\
\hline 55 & 64.532704338 & 3.7 \\
\hline 56 & 64.604384109 & 3.7 \\
\hline 19 & $220)$ \\
\hline
\end{tabular}

Table 2(c): Experimental Critical Values Obtained(3)

\section{Critical Values Trend Analyses- Metric ECFP.}

\subsection{General Procedure Adopted.}

To begin with, the tabulated data for each ECFP CV is plotted on gnuplot. Graphical analyses are then performed and general observations reported. As next step, quite some equations of fit are examined. For two $\mathrm{CVs}$, best fit is based on flat values; for another two $\mathrm{CVs}$, it is based only on values of reduced chi-square and for $3 \mathrm{CVs}$, it is based on reduced chi-square values and best extendability produced at node numbers 80 , 100 and 120. As the last step, the values of parameters for each ECFP CV equation is noted.

\subsection{Trend Analysis - ECFP CV1.}

This section is identical to figure 1 in prior paper [50] where the tendency was clearly linear increasing.

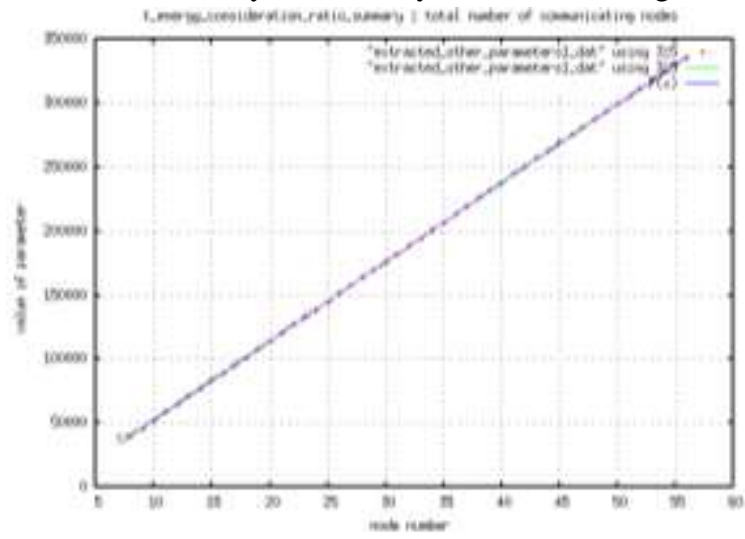

Figure 1: ECFP Critical Value 1

$$
\begin{array}{rlrl}
F(x) & =d^{*} \mathrm{x}+\mathrm{f} & \\
\text { Ch_sq }=870696 & \mathrm{~F}(80)=484951.386746697 \\
\mathrm{~F}(100)=608471.587466984 & \mathrm{~F}(120)=731991.788187272
\end{array}
$$

The parameters obtained for best fit are:

$$
\mathrm{d}=6176.01, \mathrm{f}=-9129.42
$$

\subsection{Trend Analysis - ECFP CV2.}

Here, the value has remained at 0.0 for all node numbers, and will apply for node numbers above 56 .

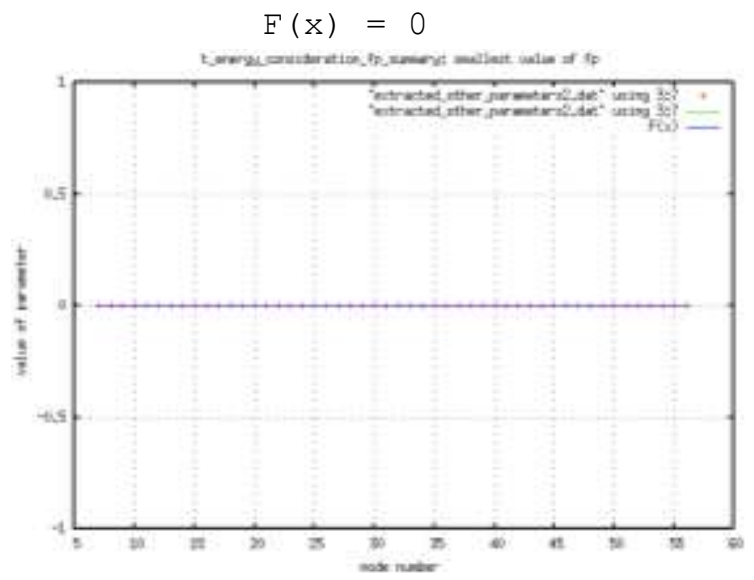

Figure 2: ECFP Critical Value 2

\subsection{Trend Analysis - ECFP CV3.}

The curve obtained here depicts a decreasing tendency at a decreasing rate.

The potentially applicable equations are:

$$
\text { 1. } F(x)=a * \exp ((b \star x)+c)+d
$$


Proc. of The Seventh Intl. Conf. On Advances In Computing, Control And Networking - ACCN 2017 Copyright (C) Institute of Research Engineers and Doctors, USA .All rights reserved. ISBN: 978-1-63248-134-4 doi: 10.15224/ 978-1-63248-134-4-01

$$
\begin{array}{cl}
\text { Ch_sq }=0.502058 & F(80)=2.946302622 \\
F(100)=2.945975793 & F(120)=2.945959776 \\
2 . F(x)=a * \exp & ((b * x)+c)+d * x^{-1}
\end{array}
$$$$
\text { Ch_sq }=0.164476 \quad \mathrm{~F}(80)=1.546051057
$$$$
\mathrm{F}(100)=1.236840845 \quad \mathrm{~F}(120)=1.030700704
$$$$
\text { 3. } F(x)=a * x^{0.25} * \exp ((b * x)+c)+d
$$$$
\text { Ch_sq }=0.583446 \quad \mathrm{~F}(80)=3.033522167
$$$$
\mathrm{F}(100)=3.033423807 \quad \mathrm{~F}(120)=3.033420706
$$

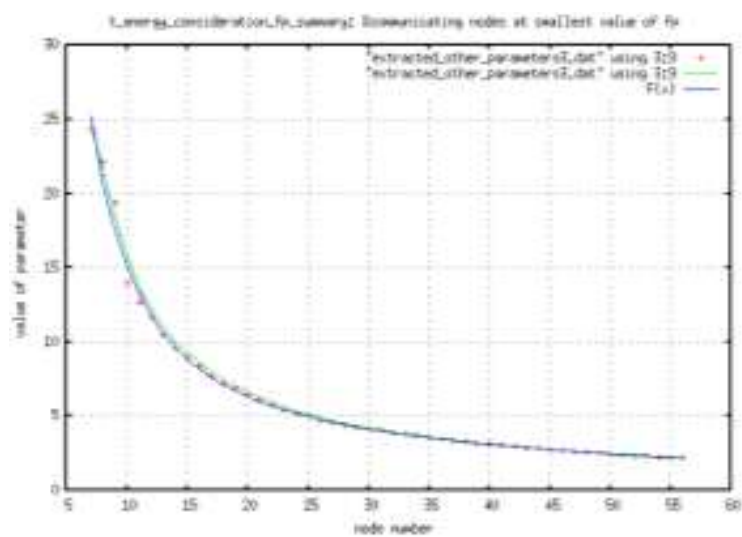

Figure 3: ECFP Critical Value 3

\section{Choice of best fit for ECFP Critical Value 3}

The equation in part 2 above has been selected because of smallest ch_sq and good extendability. The parameters obtained for best fit are:

$\mathrm{a}=6.95585, \mathrm{~b}=-0.31454, \mathrm{c}=2.28652, \mathrm{~d}=123.684$

\subsection{Trend Analysis - ECFP CV4.}

Generally the CV increases linearly with node number.

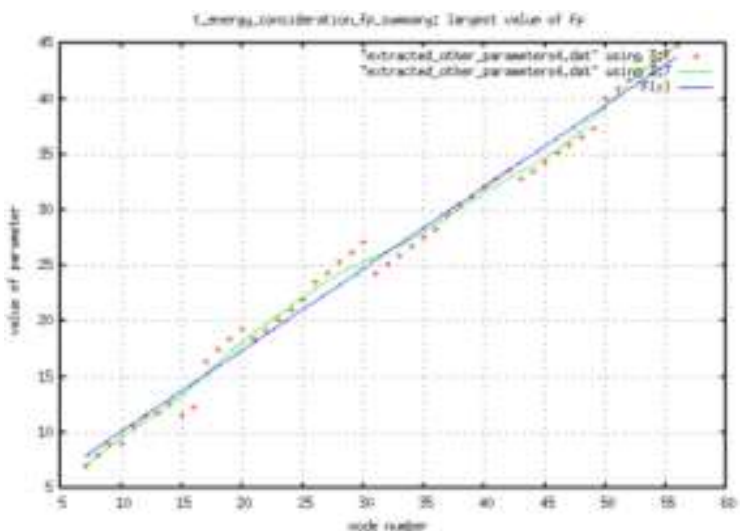

Figure 4: ECFP Critical Value 4

The potentially applicable equations are:

$$
\begin{array}{rlrl}
\text { 1. } F(x) & =d * x+f & \\
\text { Ch_sq } & =1.4928 & & F(80)=61.459899519 \\
F(100) & =76.150992128 & F(120)=90.842084737 \\
2 . F(x) & =a * \exp \quad((b * x)+c)+d \\
\text { Ch_sq } & =1.61389 & & F(80)=63.143949589 \\
F(100) & =79.743025786 & F(120)=97.054671879
\end{array}
$$

$$
\begin{array}{rlrl}
\text { 3. } \mathrm{F}(\mathrm{x}) & =\mathrm{a} * \log ((\mathrm{b} \star \mathrm{x})+\mathrm{C})+\mathrm{d} \\
\text { Ch_sq } & =1.54351 & & \mathrm{~F}(80)=59.409404554 \\
\mathrm{~F}(100) & =84.040589333 & & \mathrm{~F}(120)=84.040589333
\end{array}
$$

\section{Choice of best fit for ECFP Critical Value 4}

The equation in part 1 above has been selected because of smallest ch_sq and good extendability. parameters obtained for best fit are: $\quad d=0.734555, f=2.69553$

\subsection{Trend Analysis - ECFP CV5.}

The first 3 plots appear as outliers. As from the fourth plot, the curve is more clearly decreasing at a decreasing rate.

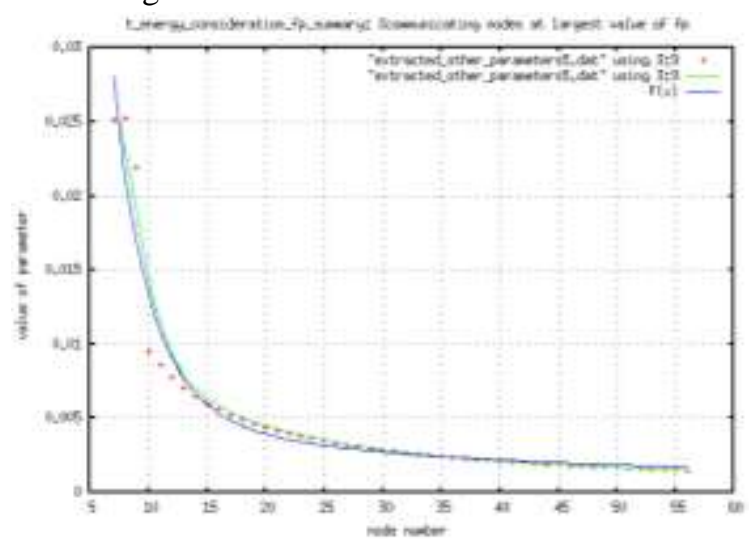

Figure 5: ECFP Critical Value 5

The potentially applicable equations are:

1. $\mathrm{F}(\mathrm{x})=\mathrm{a} * \exp ((\mathrm{b} * \mathrm{x})+\mathrm{c})+\mathrm{d}$

$$
\begin{array}{ll}
\text { Ch_sq }=1.88714\left(\mathrm{e}^{-06}\right) & \mathrm{F}(80)=0.002342089 \\
\mathrm{~F}(100)=0.002342089 & \mathrm{~F}(120)=0.002342089
\end{array}
$$

2. $\mathrm{F}(\mathrm{x})=\mathrm{a} * \exp ((\mathrm{b} * \mathrm{x})+\mathrm{c})+\mathrm{d} * \mathrm{x}^{-0.5}$

$$
\begin{array}{ll}
\text { Ch_sq }=1.62386\left(\mathrm{e}^{-06}\right) & \mathrm{F}(80)=0.001633196 \\
\mathrm{~F}(100)=0.001460774 & \mathrm{~F}(120)=0.001333499
\end{array}
$$

3. $\mathrm{F}(\mathrm{x})=\mathrm{a} * \exp ((\mathrm{b} * \mathrm{x})+\mathrm{c})+\mathrm{d} * \mathrm{x}^{-0.75}$

Ch_sq $=1.57112\left(\mathrm{e}^{-06}\right) \quad \mathrm{F}(80)=0.001304417$

$\mathrm{F}(100)=0.001103402 \quad \mathrm{~F}(120)=0.000962383$

4. $\mathrm{F}(\mathrm{x})=\mathrm{a} * \exp ((\mathrm{b} * \mathrm{x})+\mathrm{c})+\mathrm{d}^{*} \mathrm{x}^{-1}$

$$
\text { Ch_sq }=1.60558\left(\mathrm{e}^{-06}\right) \quad \mathrm{F}(80)=0.001001730
$$$$
\mathrm{F}(100)=0.000801384 \quad \mathrm{~F}(120)=0.000667820
$$

\section{Choice of best fit for ECFP Critical Value 5}

The equation in part 3 above has been selected because of smallest ch_sq and good extendability. The parameters obtained for best fit are:

$a=0.21046, b=-0.377736, c=0.109637, d=$ 0.0801385

\subsection{Trend Analysis - ECFP CV6.}

Here, mostly 2 ranges are observed. Within each range, the critical value is constant. 
Proc. of The Seventh Intl. Conf. On Advances In Computing, Control And Networking - ACCN 2017 Copyright (C) Institute of Research Engineers and Doctors, USA .All rights reserved. ISBN: 978-1-63248-134-4 doi: 10.15224/ 978-1-63248-134-4-01

$$
\mathrm{F}(\mathrm{x})=\left\{\begin{array}{cc}
0.2 & 7 \leq \mathrm{x} \leq 16 \\
0.1 & \mathrm{x} \geq 17
\end{array}\right.
$$

For $\mathrm{x}$ values above $56, \mathrm{CV}$ is projected to stay at 0.1 .

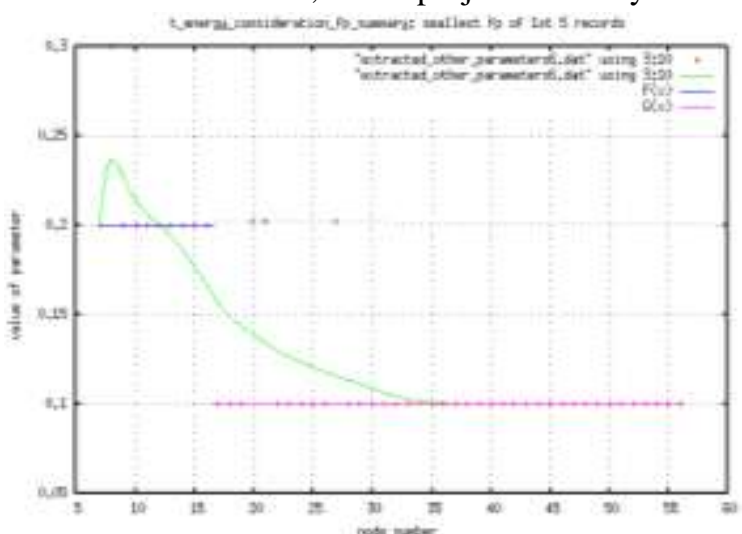

Figure 6: ECFP Critical Value 6

\subsection{Trend Analysis - ECFP CV7.}

The curve obtained here, depicts a sudden rise in the beginning until a maximum point and then follows a smoother fall.

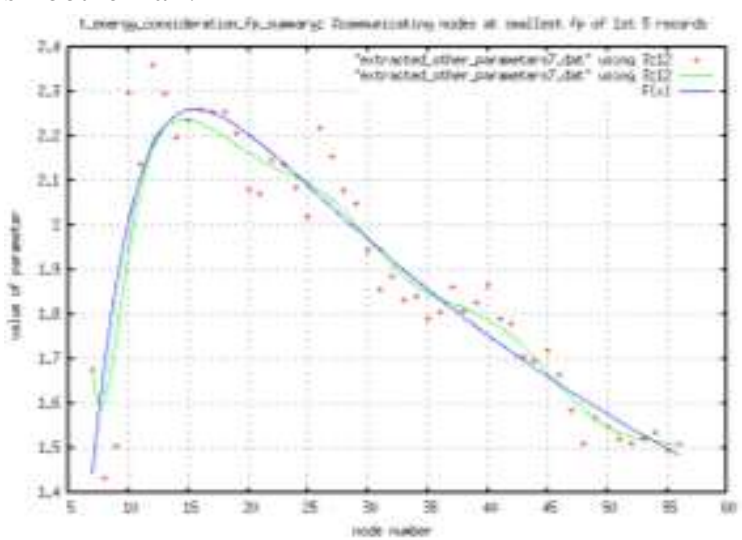

Figure 7: ECFP Critical Value 7

The potentially applicable equations are:

$$
\begin{aligned}
& \text { 1. } F(x)=\left(\left(a * x^{f}\right)+g\right) /(\exp ((b * x)+c)+d) \\
& \text { Ch_sq }=0.0124471 \quad \mathrm{~F}(80)=1.181784208 \\
& \mathrm{~F}(100)=1.008891552 \quad \mathrm{~F}(120)=0.876609819 \\
& \text { 2. } F(x)=\left(\left(a * x^{f}\right)+g\right) /\left(\exp ((b * x)+c)+\left(d * x^{-2}\right)\right) \\
& \text { Ch_sq }=0.0128178 \quad \mathrm{~F}(80)=1.114417731 \\
& \mathrm{~F}(100)=0.904674932 \quad \mathrm{~F}(120)=0.740009716 \\
& \text { 3. } F(x)=\left(\left(a * x^{f}\right)+g\right) /\left(\exp ((b * x)+c)+\left(d * x^{-3}\right)\right) \\
& \text { Ch_sq }=0.0118441 \\
& \mathrm{~F}(80)=1.184092755 \\
& \mathrm{~F}(100)=0.997061545 \quad \mathrm{~F}(120)=0.847382940 \\
& \text { 4. } F(x)=\left(\left(a^{\star} x^{f}\right)+g\right) /\left(\exp ((b * x)+C)+\left(d^{\star} x^{-4}\right)\right) \\
& \text { Ch_sq }=0.0124096 \\
& \mathrm{~F}(80)=1.108158295 \\
& \mathrm{~F}(100)=0.877205830 \\
& \mathrm{~F}(120)=0.693908985 \\
& \text { 5. } F(x)=\left(\left(a^{*} x^{f}\right)+g\right) /\left(\exp ((b * x)+c)+\left(d^{\star} x^{-2.75}\right)\right) \\
& \text { Ch_sq }=0.0118375 \\
& \mathrm{~F}(80)=1.186691099 \\
& \mathrm{~F}(100)=0.999575571 \\
& \mathrm{~F}(120)=0.845949821 \\
& \text { 6. } F(x)=\left(\left(a * x^{f}\right)+g\right) /\left(\exp ((b * x)+c)+\left(d * x^{-2 \cdot 8}\right)\right)
\end{aligned}
$$

$$
\begin{array}{ll}
\text { Ch_sq }=0.0118283 & F(80)=1.190830014 \\
F(100)=1.005642105 & F(120)=0.853755707
\end{array}
$$

\section{Choice of best fit for ECFP Critical Value 7}

The equation in part 6 above has been selected because of smallest ch_sq and good extendability. The parameters obtained for best fit are:

$\mathrm{a}=1.6284, \mathrm{~b}=-0.000140682, \mathrm{c}=-4.80282, \mathrm{~d}=$

$2.36608, \mathrm{f}=-0.00430099, \quad \mathrm{~g}=-1.58832$

\subsection{Trend Analysis - ECFP CV8.}

Here, mostly 2 sets of observations for trends are made:

i. For node numbers 12 until 36, a mostly linear trend with small positive gradient is observed with values between 33 and 35 .

ii. For node numbers 37 until 56, a mostly linear trend with small negative gradient is observed with values between 22 and 24 .

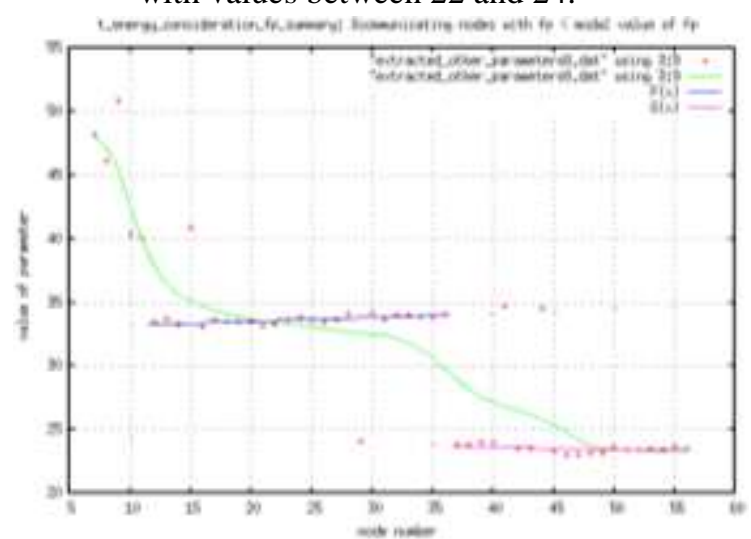

Figure 8: ECFP Critical Value 8

For node numbers 7 until 11, no observable trend is found, only that values are between 40 and 51 .

$\mathrm{F}(\mathrm{x})$

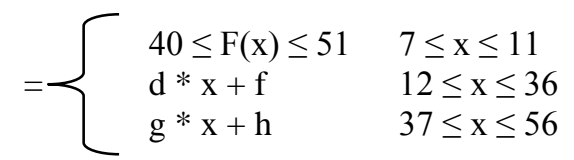

For node numbers 12-36 : ch_sq $=0.0498651, \mathrm{~d}=$ $0.0309017, f=32.8986$

For node numbers 37-56: ch_sq $=0.0721955, \mathrm{~g}=$ $0.0229244, \mathrm{~h}=24.5496$

Suggestion: Equation " $\mathrm{F}(\mathrm{x})=\mathrm{g} * \mathrm{x}+\mathrm{h}$ " may serve for prediction over larger node numbers.

\subsection{Trend Analysis - ECFP CV9.}

Here also, two sets of observations for trends are made:

i. For node numbers 12 until 36, a mostly decreasing trend at a decreasing rate with values between 55 and 60 .

ii. For node numbers 37 until 56, a mostly decreasing trend at a decreasing rate with values between 64 and 66 . 


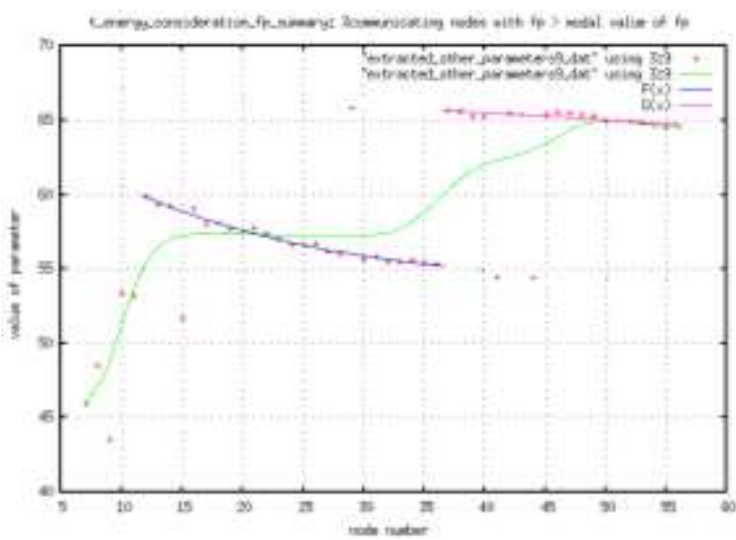

Figure 9: ECFP Critical Value 9

For node number 7 until 11, no observable trend is found, only that the values are between 43 and 54 .

$F(x)= \begin{cases}43 \leq F(x) \leq 54 & 7 \leq x \leq 11 \\ a * \exp ((b * x)+c)+d & 12 \leq x \leq 36 \\ f * x+g & 37 \leq x \leq 56\end{cases}$

For node numbers 12-36 : ch_sq $=0.0460789, \mathrm{a}=2.27067, \mathrm{~b}=-$ $0.0571109, \mathrm{c}=1.69028, \mathrm{~d}=53.6719$

For node numbers $37-56$, two possibilities were tried:

1. $\quad \mathrm{F}(\mathrm{x})=\mathrm{f} * \exp ((\mathrm{g} * \mathrm{x})+\mathrm{h})+\mathrm{i})$ Ch_sq $=0.048543$

$$
\begin{array}{ll}
\mathrm{f}=2.10014 & \mathrm{~g}=-0.00495207 \\
\mathrm{~h}=1.78031 & \mathrm{i}=55.2987
\end{array}
$$

2. $\mathrm{F}(\mathrm{x})=\mathrm{f} * \mathrm{x}+\mathrm{g}$

$$
\text { Ch_sq }=0.041330
$$

$$
\mathrm{f}=-0.0496308 \quad \mathrm{~g}=67.5061
$$

Here, the equation in part 2 above has been selected because of least ch_sq. This same equation may be used for prediction over larger node numbers.

\subsection{Trend Analysis - ECFP CV10.}

Here values are rounded to 1 d.p. Else, from smooth bezier, the trend is noted increasing at a decreasing rate.

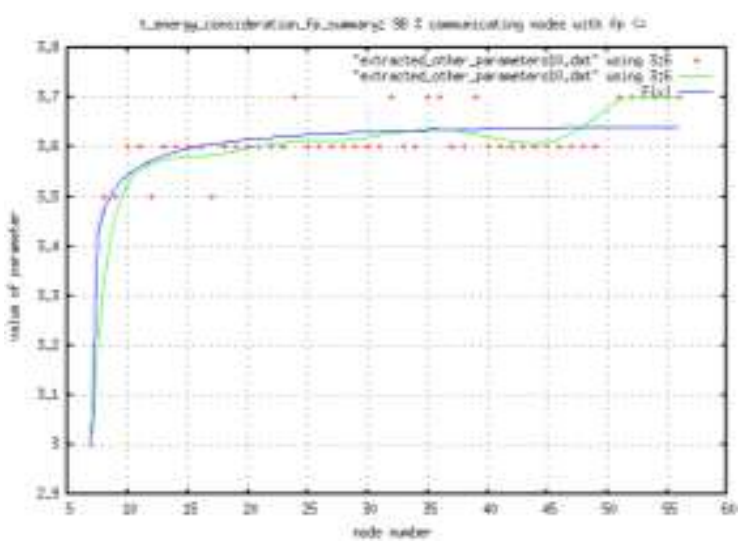

Figure 10: ECFP Critical Value 10

The potentially applicable equations are:

$$
\text { 1. } F(x)=a * \log ((b * x)+c)+d
$$

$$
\begin{aligned}
& \text { Ch_sq }=0.00319057 \quad \mathrm{~F}(80)=3.682200599 \\
& \mathrm{~F}(100)=3.694010743 \quad \mathrm{~F}(120)=3.703511286 \\
& \text { 2. } F(x)=a * x^{-0.1} * \log ((b * x)+c)+d \\
& \text { Ch_sq }=0.00262017 \quad \mathrm{~F}(80)=3.676575717 \\
& F(100)=3.685203834 \quad F(120)=3.691749283 \\
& \text { 3. } F(x)=a * x^{-0.25} * \log ((b * x)+c)+d \\
& \text { Ch_sq }=0.00259389 \quad \mathrm{~F}(80)=3.642705471 \\
& \mathrm{~F}(100)=3.642823581 \quad \mathrm{~F}(120)=3.642446376
\end{aligned}
$$

\section{Choice of best fit for ECFP Critical Value 10}

The equation in part 3 above has been selected because of smallest ch_sq and good extendability. The parameters obtained for best fit are: $\mathrm{a}=0.11643, \mathrm{~b}=0.881716, \mathrm{c}=-6.17078, \mathrm{~d}=3.48057$

\section{Conclusion.}

This study had as objective to identify some CVs applicable to metric ECFP and study their corresponding trends over varying node densities in a MANET topography of $300 \times 300 \mathrm{~m}^{2}$. The models formulated in this paper comprise of quite complex mathematical equations. The results illustrated here will reinforce our existing tools for better studies of MANETs for ubicomp environment from the angle of software engineering. These output can methodically be implemented in computational algorithms to produce more realistic simulation schemes which may in turn serve for conducting better testing procedure of communication protocols and middleware components.

This experiment was carried out in NS-2 over Linux. Plottings and "Fit" attempts were done in gnuplot. selection of best fit was made based on a combination of flat values, least reduced chi-square values and best extendability produced at higher node numbers. Assumptions illustrated in previous studies [22, 38] are maintained here also.

This study stands as a follow-up of previous studies [153 ] and remains open for future upgrades. A future task remains the formulation of predictability for metric ECFP and its trend.

\section{References}

[1] M. Kaleem GALAMALI, Assoc. Prof Nawaz MOHAMUDALLY, Towards Dependable Pervasive Systems-A Position and Vision Paper, CEET 2014

[2] M. Kaleem GALAMALI, Assoc. Prof Nawaz MOHAMUDALLY, Model of Energy Savings achievable with Location-aware Node-to-Node Transmission in UbiComp , CEET 2014

[3] M. Kaleem GALAMALI, Assoc. Prof Nawaz MOHAMUDALLY, Model of Energy Savings achievable with Location-aware Node-to-Node Transmission in UbiComp Using Location Refresh Intervals, CEET 2014

[4] M. Kaleem GALAMALI, Assoc. Prof Nawaz 
MOHAMUDALLY, Model of Energy Savings achievable with Location-aware Transmission in UbiComp Using Relays, CEET 2014

[5] M. Kaleem GALAMALI, Assoc. Prof Nawaz MOHAMUDALLY, Mathematical modeling of need of exact number of relays to ensure seamless mobility in mobile computing, CEET 2014

[6] M. Kaleem GALAMALI, Assoc. Prof Nawaz MOHAMUDALLY, Modelling of need for multiple relays for ensuring seamless mobility, CEET 2014

[7] M. Kaleem GALAMALI, Assoc. Prof Nawaz MOHAMUDALLY, Investigation of prominence of placements of relays in a ubicomp topography,

[8] M. Kaleem GALAMALI, Assoc. Prof Nawaz MOHAMUDALLY, Model of energy savings achievable with location-aware transmission in ubicomp using optimised number of relays.

[9] M. Kaleem GALAMALI, Assoc. Prof Nawaz MOHAMUDALLY, Investigation of Prominence of Placements of Optimised Number of Relays in a Ubicomp Topography using Location-Aware Transmission, CEET 2015.

[10] M. Kaleem GALAMALI, Assoc. Prof Nawaz MOHAMUDALLY, Extending Node Battery Availability in Ubicomp with Location-Aware Transmission, CEET 2015.

[11] M. Kaleem GALAMALI, Assoc. Prof Nawaz MOHAMUDALLY, Extending Node Battery Availability in Ubicomp with Location-Aware Transmission using Location Refresh Intervals, CEET 2015.

[12] M. Kaleem GALAMALI, Assoc. Prof Nawaz MOHAMUDALLY, Extending Node Battery Availability in Ubicomp with Location-Aware Transmission using Uniformly Placed Relays, CEET 2015.

[13] M. Kaleem GALAMALI, Assoc. Prof Nawaz MOHAMUDALLY, Extending Node Battery Availability in Ubicomp with Location-Aware Transmission Using Optimally Placed Relays, CEET 2015.

[14] M. Kaleem GALAMALI, Assoc. Prof Nawaz MOHAMUDALLY, Model of Sender Node Energy Savings Achievable with Location-Aware MANET Transmission in Ubicomp. ACCN 2016

[15] M. Kaleem GALAMALI, Assoc. Prof Nawaz MOHAMUDALLY, Model of Overall Node Energy Savings Achievable with Location-Aware MANET Transmission in Ubicomp. ACCN 2016

[16] M. Kaleem GALAMALI, Assoc. Prof Nawaz MOHAMUDALLY, Model of Sender Node Extra Energy Savings Achievable in MANET Against Direct Node-toNode Transmission Using Location-Aware Transmission in Ubicomp. ACCN 2016

[17] M. Kaleem GALAMALI, Assoc. Prof Nawaz MOHAMUDALLY, Model of Overall Node Extra Energy Savings Achievable in MANET against Direct Node-toNode Transmission Using Location-Aware Transmission in Ubicomp. ACCN 2016

[18] M. Kaleem GALAMALI, Assoc. Prof Nawaz MOHAMUDALLY, Model of Energy Consumption Ratio Achievable in MANET Using Location-Aware Transmission in Ubicomp. ACCN 2016

[19] M. Kaleem GALAMALI, Assoc. Prof Nawaz MOHAMUDALLY, Model of Minimum Energy Consumption Ratio Achievable in MANET Using LocationAware Transmission in Ubicomp. ACCN 2016

[20] M. Kaleem GALAMALI, Assoc. Prof Nawaz MOHAMUDALLY, Model of Maximum Energy Consumption Ratio Achievable in MANET Using LocationAware Transmission in Ubicomp. ACCN 2016

[21] M. Kaleem GALAMALI, Assoc. Prof Nawaz

MOHAMUDALLY, Model of Overall Energy Consumption Fairness Ratio Achievable in MANET Using LocationAware Transmission in Ubicomp. ACCN 2016

[22] M. Kaleem GALAMALI, Assoc. Prof Nawaz MOHAMUDALLY, Model of Overall Energy Consumption Fairness Proportion Achievable in MANET Using LocationAware Transmission for Ubicomp, CEET 2016

[23] M. Kaleem GALAMALI, Assoc. Prof Nawaz MOHAMUDALLY, Model of Minimum Fairness Proportion Achievable in MANET Using Location-Aware Transmission for Ubicomp, CEET 2016

[24] M. Kaleem GALAMALI, Assoc. Prof Nawaz
MOHAMUDALLY, Model of Maximum Fairness Proportion Achievable in MANET Using Location-Aware Transmission for Ubicomp, CEET 2016

[25] M. Kaleem GALAMALI, Assoc. Prof Nawaz MOHAMUDALLY, Model of Sender Fairness Proportion Achievable in MANET Using Location-Aware Transmission for Ubicomp, CEET 2016

[26] M. Kaleem GALAMALI, Assoc. Prof Nawaz MOHAMUDALLY, Model of Distance Travelled by packets in MANETs using Location-Aware Transmission for Ubicomp, CEET 2016

[27] M. Kaleem GALAMALI, Assoc. Prof Nawaz MOHAMUDALLY, Model of Maximum CBR Distance Travelled by packets in MANETs using Location-Aware Transmission for Ubicomp, CEET 2016

[28] M. Kaleem GALAMALI, Assoc. Prof Nawaz MOHAMUDALLY, Model of Minimum CBR Distance Travelled by packets in MANETs using Location-Aware Transmission for Ubicomp, CEET 2016

[29] M. Kaleem GALAMALI, Assoc. Prof Nawaz MOHAMUDALLY, Model of Range CBR Distance Experienced by Transmissions in MANETs using LocationAware Transmission for Ubicomp, CEET 2016

[30] M. Kaleem GALAMALI, Assoc. Prof Nawaz MOHAMUDALLY, Trend Analyses of Parameters of Equations for Sender Node Energy Savings Achievable in ubicomp MANETs using Location-Aware Transmission, ACCN 2017.

[31] M. Kaleem GALAMALI, Assoc. Prof Nawaz MOHAMUDALLY, Trend Analyses of Parameters of Equations for Overall Node Energy Savings Achievable in ubicomp MANETs using Location-Aware Transmission, ACCN 2017.

[32] M. Kaleem GALAMALI, Assoc. Prof Nawaz MOHAMUDALLY, Trend Analyses of Parameters of Equations for Sender Node Extra Energy Savings Achievable in MANET against Direct Node-to-Node Location-Aware Transmission, ACCN 2017.

[33] M. Kaleem GALAMALI, Assoc. Prof Nawaz MOHAMUDALLY, Trend Analyses of Parameters of Equations for Overall Nodes Extra Energy Savings Achievable in MANET against Direct Node-to-Node Location-Aware Transmission, ACCN 2017.

[34] M. Kaleem GALAMALI, Assoc. Prof Nawaz MOHAMUDALLY, Trend Analyses of Parameters of Equations for Energy Consumption Ratio Achievable in Ubicomp MANET Using Location-Aware Transmission, ACCN 2017.

[35] M. Kaleem GALAMALI, Assoc. Prof Nawaz MOHAMUDALLY, Trend Analyses of Parameters of Equations for Minimum Energy Consumption Ratio Achievable in Ubicomp MANETs Using Location-Aware Transmission, ACCN 2017.

[36] M. Kaleem GALAMALI, Assoc. Prof Nawaz MOHAMUDALLY, Trend Analyses of Parameters of Equations for Maximum Energy Consumption Ratio Achievable in Ubicomp MANETs Using Location-Aware Transmission, ACCN 2017.

[37] M. Kaleem GALAMALI, Assoc. Prof Nawaz MOHAMUDALLY, Trend Analyses of Parameters of Equations for Overall Fairness Ratio Achievable in Ubicomp MANETs Using Location-Aware Transmission, ACCN 2017.

[38] M. Kaleem GALAMALI, Assoc. Prof Nawaz MOHAMUDALLY, Trend Analyses of Parameters of Equations for Energy Consumption Fairness Proportion Achievable in Ubicomp MANETs Using Location-Aware Transmission, CEET 2017

[39] M. Kaleem GALAMALI, Assoc. Prof Nawaz MOHAMUDALLY, Trend Analyses of Parameters of Equations for Minimum Fairness Proportion Achievable in Ubicomp MANETs Using Location-Aware Transmission, CEET 2017

[40] M. Kaleem GALAMALI, Assoc. Prof Nawaz MOHAMUDALLY, Trend Analyses of Parameters of Equations for Maximum Fairness Proportion Achievable in Ubicomp MANETs Using Location-Aware Transmission, CEET 2017

[41] M. Kaleem GALAMALI, Assoc. Prof Nawaz MOHAMUDALLY, Trend Analyses of Parameters of Equations for Sender Fairness Proportion Achievable in Ubicomp MANETs Using Location-Aware Transmission, CEET 2017

[42] M. Kaleem GALAMALI, Assoc. Prof Nawaz 
MOHAMUDALLY, Trend Analyses of Parameters of Equations for Packets Per Distance Achievable in Ubicomp MANETs Using Location-Aware Transmission, CEET 2017

[43] M. Kaleem GALAMALI, Assoc. Prof Nawaz MOHAMUDALLY, Trend Analyses of Parameters of Equations for Maximum CBR Distance Achievable in Ubicomp MANETs Using Location-Aware Transmission, CEET 2017

[44] M. Kaleem GALAMALI, Assoc. Prof Nawaz MOHAMUDALLY, Trend Analyses of Parameters of Equations for Minimum CBR Distance Achievable in Ubicomp MANETs Using Location-Aware Transmission, CEET 2017

[45] M. Kaleem GALAMALI, Assoc. Prof Nawaz MOHAMUDALLY, Trend Analyses of Parameters of Equations for Range CBR Distance Achievable in Ubicomp MANETs Using Location-Aware Transmission, CEET 2017

[46] M. Kaleem GALAMALI, Assoc. Prof Nawaz MOHAMUDALLY, Trend Analyses of Critical Values Obtained for Sender Node Energy Savings Achievable in Ubicomp MANETs Using Location-Aware Transmission, CEET 2017

[47] M. Kaleem GALAMALI, Assoc. Prof Nawaz MOHAMUDALLY, Trend Analyses of Critical Values Obtained for Overall Node Energy Savings Achievable in Ubicomp MANETs Using Location-Aware Transmission, CEET 2017

[48] M. Kaleem GALAMALI, Assoc. Prof Nawaz MOHAMUDALLY, Trend Analyses of Critical Values Obtained for Sender Node Extra Energy Savings Achievable in Ubicomp MANET Against Direct Node-to-Node Location-Aware Transmission, CEET 2017

[49] M. Kaleem GALAMALI, Assoc. Prof Nawaz MOHAMUDALLY, Trend Analyses of Critical Values Obtained for Overall Nodes Extra Energy Savings Achievable in Ubicomp MANET Against Direct Node-toNode Location-Aware Transmission, CEET 2017

[50] M. Kaleem GALAMALI, Assoc. Prof Nawaz MOHAMUDALLY, Trend Analyses of Critical Values Obtained for Energy Consumption Ratio Achievable in Ubicomp MANETs Using Location-Aware Transmission Strategies, CEET 2017

[51] M. Kaleem GALAMALI, Assoc. Prof Nawaz MOHAMUDALLY, Trend Analyses of Critical Values Obtained for Minimum Energy Consumption Ratio Achievable in Ubicomp MANETs Using Location-Aware Transmission Strategies, CEET 2017

[52] M. Kaleem GALAMALI, Assoc. Prof Nawaz MOHAMUDALLY, Trend Analyses of Critical Values Obtained for Maximum Energy Consumption Ratio Achievable in Ubicomp MANETs Using Location-Aware Transmission Strategies, CEET 2017

[53] M. Kaleem GALAMALI, Assoc. Prof Nawaz MOHAMUDALLY, Trend Analyses of Critical Values Obtained for Overall Fairness Ratio Achievable in Ubicomp MANETs Using Location-Aware Transmission Strategies, CEET 2017

[54] Markus Bylund and Zary Segall, Towards seamless mobility with personal servers, 2004.

[55] Masugi Inoue, Mikio Hasegawa, Nobuo Ryoki and Hiroyuki Morikawa, Context-Based Seamless Network and Application Control, 2004

[56] Xiang Song, Umakishore Ramachandran, MobiGo: A Middleware for Seamless Mobility, College of Computing Georgia Institute of Technology, Atlanta, GA, USA, August 2007

[57] Budzisz, Ferrús, R., Brunstrom A., Grinnemo, K, Fracchia, R., Galante, G., and Casadevall, F. Towards transport-layer mobility: Evolution of SCTP multihoming, March 2008

[58] Paul Dourish \& Genevieve Bell, Divining a digital future, 2011.

[59] Xiang Song, Seamless Mobility In Ubiquitous Computing Environments, PhD Thesis, Georgia Institute of Technology, August 2008

[60] Kevin O Mahony, Jian Liang, Kieran Delaney, User-Centric Personalization and Autonomous Reconfiguration Across Ubiquitous Computing Environments, NIMBUS Centre Cork Institute of Technology, Cork, Ireland, UBICOMM 2012

[61] Pablo Vidales, Seamless mobility in 4G systems, Technical
Report, University of Cambridge, Computer Laboratory, Number 656, November 2005

[62] João Pedro Sousa and David Garlan, Aura: An Architectural Framework for User Mobility in Ubiquitous Computing Environments, School of Computer Science, Carnegie Mellon University, USA, August 2002

[63] Dennis Lupiana, Ciaran O’Driscoll, Fredrick Mtenzi, Defining Smart Space in the Context of Ubiquitous Computing, Dublin Institute of Technology, Ireland, Special Issue on ICIT 2009 Conference - Web and Agent Systems, 2009

[64] N.S.V.Shet1, Prof.K.Chandrasekaran2 and Prof. K.C.Shet3, WAP Based Seamless Roaming In Urban Environment with Wise Handoff Technique, International Journal of UbiComp (IJU), Vol.1, No.4, October 2010

[65] Yipeng Yu Dan He Weidong Hua Shijian Li Yu Qi Yueming Wang Gang Pan, FlyingBuddy2: A Braincontrolled Assistant for the Handicapped, Zhejiang University, UbiComp'12, September 5-8, 2012.

[66] Jing Su, James Scott, Pan Hui, Jon Crowcroft, Eyal de Lara Christophe Diot, Ashvin Goel, Meng How Lim, and Eben Upton, Haggle: Seamless Networking for Mobile Applications, 2007

[67] Rui Han, Moustafa M. Ghanem, Li Guo, Yike Guo*, Michelle Osmond, Enabling cost-aware and adaptive elasticity of multi-tier cloud applications, Future Generation Computer Systems, 2012

[68] Byrav Ramamurthy, K. K. Ramakrishnan, Rakesh K. Sinha, Cost and Reliability Considerations in Designing the NextGeneration IP over WDM Backbone Networks, 2012

[69] Bhavish Aggarwal, Aditya Akella, Ashok Anand, Athula Balachandran, Pushkar Chitnis, Chitra Muthukrishnan, Ram Ramjee and George Varghese, EndRE: An End-System Redundancy Elimination Service for Enterprises, NSDI 2010, San Jose, CA

[70] Ashok Anand, Vyas Sekar and Aditya Akella, SmartRE: An Architecture for Coordinated Network-wide Redundancy Elimination, SIGCOMM 2009, Barcelona, Spain

[71] John Breeden II, "Smart-phone battery life could double without better batteries", Nov 14, 2012

[72] Andy Boxall, "When will your phone battery last as long as your kindle", December 5, 2012.

[73] Imielinski, T. and Navas, J.C. (1999). GPS-based geographic addressing, routing, and resource discovery. Comms. ACM, Vol. 42, No. 4, pp. 86-92.

[74] Hightower, J. and Borriello, G. (2001). Location Systems for Ubiquitous Computing. IEEE Computer, Vol. 34, No. 8 , August, pp. 57-66.

[75] Harter, A., Hopper, A., Steggles, P., Ward, A. and Webster, P. (2002). The Anatomy of a Context-Aware Application. Wireless Networks, Vol. 8, No. 2-3, Mar-May, pp. 187-197.

[76] Hightower, J., Brumitt, B. and Borriello, G. (2002). The Location Stack: A Layered Model for Location in Ubiquitous Computing. Proceedings of the 4th IEEE Workshop on Mobile Computing Systems \& Applications (WMCSA 2002), Callicoon, NY, USA, June, pp. 22-28.

[77] Graumann, D., Lara, W., Hightower, J. and Borriello, G. (2003) Real-world implementation of the Location Stack: The Universal Location Framework. Proceedings of the 5th IEEE Workshop on Mobile Computing Systems \& Applications (WMCSA 2003), Monterey, CA, USA, October, pp. 122-128.

[78] Ko, Y., \& Vaidya, N. H. (2000). Location-aided routing (LAR) in mobile ad hoc networks. Wireless Networks, 6(4), 307-321.

[79] Liao, W.-H., Tseng, Y.-C., \& Sheu, J.-P. (2001). GRID: a fully location-aware routing protocol for mobile ad hoc networks. Telecommunication Systems, 18(1), 37-60.

[80] Kuhn, F., Wattenhofer, R., Zhang, Y., \& Zollinger, A. (2003). Geometric ad-hoc routing: of theory and practice. In Proceedings of the ACM (PODC'03) (pp. 63-72).

[81] Jiang, X., \& Camp, T. (2002). Review of geocasting protocols for a mobile ad hoc network. In Proceedings of the Grace Hopper Celebration (GHC)

[82] Ko, Y. \& Vaidya, N. H. (1999). Geocasting in mobile ad hoc networks: location-based multicast algorithms. In Proceedings of the IEEE (WMCSA'99) (pp. 101).

[83] Mauve, M., Fuler, H., Widmer, J., \& Lang, T. (2003). Position-based multicast routing for mobile ad-hoc networks (Technical Report TR-03-004). Department of Computer Science, University of Mannheim. 
[84] Xu, Y., Heidemann, J., \& Estrin, D. (2001). Geographyinformed energy conservation for adhoc routing. In Proceedings of the ACM/IEEE (MOBICOM'01) (pp. 70-84).

[85] Hu, Y.-C., Perrig, A., \& Johnson, D. (2003). Packet leashes: a defense against wormhole attacks in wireless ad hoc networks. In Proceedings of the INFOCOM'03 (pp. 1976-1986).

[86] Patwari, N., Hero III, A. O., Perkins, M., Correal, N. S., \& O'Dea, R. J. (2003). Relative location estimation in wireless sensor networks. IEEE Transactions on Signal Processing, 51(8), 2137-2148.

[87] Baldauf, M., Dustdar, S., \& Rosenberg, F. (2007). A Survey on Context Aware Systems. International Journal of Ad Hoc and Ubiquitous Computing, Inderscience Publishers. forthcoming. Pre-print from: http://www.vitalab.tuwien.ac.at/ florian/papers/ijahuc2007.pdf

[88] Hong, D., Chiu, D.K.W., \& Shen, V.Y. (2005). Requirements elicitation for the design of context-aware applications in a ubiquitous environment. In Proceedings of ICEC'05 (pp. 590-596).

[89] Neeraj Tantubay, Dinesh Ratan Gautam and Mukesh Kumar Dhariwal, A Review of Power Conservation in Wireless Mobile Ad hoc Network (MANET)", International Journal of computer Science Issues, Vol 8, Issue 4, No 1, July 2011.

[90] Wenrui Zhao, Mostafa Ammar and Ellen Zegura, "A Message Ferrying Approach for Data Delivery in Sparse Mobile Ad Hoc Networks", MobiHoc'04, May 24-26, 2004, Roppongi, Japan.

[91] Sgroi et al., "Designing Wireless Protocols: Methodology and Applications, February 2000.

[92] Gyula et al., "Simulation-based optimization of communication protocols for large-scale wireless sensor networks", 10 October 2002

[93] Rao and Sharma, "Cross Layer Protocols For Multimedia Transmission in Wireless Networks", June 2012

[94] Herms et al, "Realism in Design and Evaluation of Wireless Routing Protocols", 2007.

About Author (s):

Associate Professor Nawaz Mohamudally works at University of Technology, Mauritius (UTM) and has undertaken supervision of MPhil/PhD Students for many years.

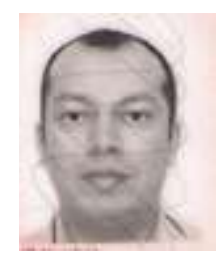

M. Kaleem Galamali is a part-time student (achieved M Phil Transfer on 28.10.2014, currently PhD student) at UTM under supervision of A.P. Nawaz Mohamudally. 